\title{
INFLATION AND TOOLS OF FINANCIAL ANALYSIS \\ IN GREECE 1973-83
}

by

John Paghios and F. Virgil Boyd*

\section{Introduction}

At a time when FASB 33 "Financial Reporting and Changing Prices" is being reconsidered it may be appropriate to examine accounting for inflation in a different setting. The U.S. has never experienced the hyper or even maxi inflation rates of many countries. Undoubtedly, this accounts for the lack of continued interest in this problem. For example, in the U.S. following World War II, there was substantial interest in the topic by both the American Institute of CPA's and the American Accounting Association, but this interest waned as the anticipated rise in prices failed to occur.

But the usefulness of a solution to this problem should not be based solely on the economic conditions at the time of the review. The real issue of usefulness is a more general one. Would statements adjusted for changes in prices produce more useful information? Would the tools of analysis such as financial ratios be significantly different if based upon adjusted rather than unadjusted data?

To examine this issue in a more useful setting than in the U.S., fifteen companies in Greece were selected as the basis for this study. Greece has experienced substantial inflation much more than the U.S., but not hyper inflation like Brazil or Israel. As a means of dealing with inflation and meeting a fiscal problem the Greek government in 1973 required all companies to reduce all of their assets to a current monetary base. Prices continued to rise during the period $1973-1983$ by $554 \%$ so the comparability of financial statements for the different years was again destroyed. The action of the government, however, is helpful to this study; as a result of this action it can be assumed that all assets acquired prior to 1973 appear in 1973 monetary units on the financial statements.

The fifteen Greek Companies selected at random consist of one steel company, three textile companies, two breweries, two food companies, and one oil company, one chemical company, two cement and fertilizer companies, one lumber company and two tobacco companies. The financial statements for each of these companies for each year 1973-1983 were adjusted for changes in the level of prices. The resulting statements were used to test three null hypotheses:

I. For each of the twenty three measures and ratios

*Tis study is based upon materials collected and used by John Paghios of Piraeus Graduate School of Industrial Studies in his doctoral dissertation. 
of the fifteen companies there will be no significant differences between those computed with adjusted data and those computed with unadjusted data for the period 1973-83.

II. For each of the twenty three measures and ratios there will be no significant difference in trends for the period 1973-83 between those based upon adjusted and unadjusted data.

III. For each year 1973 to 1983 and for each measure and ratio there will be no significant difference among companies between measures and ratios based upon adjusted and unadjusted data.

To test for differences three statistical test were used: student $t$ test, Wilcoxon nonparametric test and the univariate distribution test. Twenty three amounts and ratios frequently used in financial analysis were examined; sales, net income, total assets, owner equity, current liabilities, long term liabilities, current assets, inventory, cost of goods sold, fixed assets, working capital, inventory turnover, current ratio, net income to sales (return on sales), sales to total assets (turnover), net income to total assets (return on assets), net income to owner equity (return on equity), total liabilities to total equity, long term liabilities to total long term liabilities plus owner equity, sales to fixed assets, sales to working capital, working capital total assets, and owner equity to total assets. Thus for each year there were 345 computations (23 measures $X 15$ companies) or 3,450 computations for the ten year period in addition to the computations needed to adjust the financial statements for price change. To make the data comparable for the entire ten year period all amounts were stated in 1983 drachmas.

\section{Methodology}

The general procedure used in the adjustment process is first to identify monetary and non-monetary items on the financial statements. Monetary items are defined as those items which are fixed in monetary terms by contract or agreement. For example cash, accounts receivable and all liabilities are fixed in monetary terms. Although in real terms they may gain or lose value with changes in the general price level, their monetary values remain fixed. In contrast, inventories and physical plant represent non-monetary items with values measured in monetary terms which increase and decrease with changes in the general price level.

The fixed nature of monetary items produces gains and losses in purchasing power as economic conditions change. For example, if inflation occurs cash loses purchasing power, and liabilities produce gains in purchasing power. Greek businesses tend to have very high debt ratios, and as one would expect, this tends to produce gains in purchasing power from the monetary 
items when inflation occurs.

Once the nonmonetary items have been identified the next step is to determine the acquisition dates of each nonmonetary item which appears on the financial statement. It may be impractical or even impossible to determine the exact dates of all acquisitions but operationally useful assumptions can be made. For example, it is often assumed that any acquisitions which occur during a year are made at mid year. Once the acquisition dates have been determined, all of the nonmonetary items are converted from unadjusted amounts to amounts stated in year end monetary units. The conversion occurs by multiplying the unadjusted amounts by the ratio of the current year-end price index to the price index in the year of acquisition. For example, assume that land was purchased in $19 x 0$ for 100 drachmas when the price index was 50 and that the current year-end price index is 200, the conversion is 100 drachmas multiplied by 200/50, producing an adjusted amount for the land of $400 \mathrm{drach}-$ mas.

Each nonmonetary item is so adjusted. Capital stock is treated as a nonmonetary item. Retained earnings is frequently a "plugged" figure in the first adjusted balance sheet since it is almost impossible to determine the dates of every change that has occurred in the retained earnings account.

In the first adjusted balance sheet monetary items are not adjusted. Since their values in monetary terms are fixed, the monetary value at the year-end is in year-end monetary units.

See Exhibit I which follows for a demonstration of the preparation of the first adjusted balance sheet. For purposes of illustration dollars are used instead of drachmas.

\title{
Exhibit I
}

Given: $\quad \mathrm{X}$ Company was organized in $19 \mathrm{xo}$ when the price level was 50. The building was purchased when the price level was 50. The price level at the end of $19 \times 0$ was 100 .

Required: Convert the unadjusted balance sheet given below to an adjusted balance sheet stated in terms of the year-end price level.

\author{
X Company \\ Balance sheet \\ December $31,19 x 0$
}

Assets:

Cash

$\$ 100$

Liabilities and Equity

Building

500

Accum. Depreciation (100)

Common Stock
Retained Earnings

$\$ 100$

400

$\$ \underline{500}$

$\$ \underline{500}$ 
Exhibit I - SOLUTION:

X Company

\begin{tabular}{|c|c|c|c|}
\hline & Unadjusted & $\begin{array}{l}\text { Conversion } \\
\text { factor } \\
\end{array}$ & Adjusted* \\
\hline Cash (monetary) & $\$ 100$ & -- & $\$ 100$ \\
\hline Building (nonmonetary) & 500 & $100 / 50$ & 1000 \\
\hline Accum. Dep. (nonmonetary) & $\frac{(100)}{\$ 500}$ & $100 / 50$ & $\$ \frac{(200)}{900}$ \\
\hline $\begin{array}{l}\text { Common stock (nonmonetary) } \\
\text { Retained Earnings (nonmonetary) }\end{array}$ & $\begin{array}{r}\$ 100 \\
400 \\
\$ 500\end{array}$ & $\begin{array}{l}100 / 50 \\
\text { plugged }\end{array}$ & $\begin{array}{r}200 \\
\quad \$ 900 \\
\$ 900\end{array}$ \\
\hline
\end{tabular}

*adjusted to December 31, $19 x 0$ dollars.

If one is to proceed to prepare an income statement for the next year and a balance sheet as of the end of that year, the first step is to roll all of the balance sheet accounts forwaxd by multiplying by a factor of the price index at the end of year 2 over the price index at the end of year 1. Thus the opening balances for the year 2 are stated in end of year 2 price levels.

Changes in any of the balance sheet accounts during year 2 are assumed to occur at the average price level for the year; thus, sales, purchases, and most operating expenses are in average price level units. To restate these in year-end monetary units a conversion factor consisting of the ratio of the year-end price level to the average price level is used. However, since these revenue and expense items produce or use monetary items in most cases, recognition must be given to the gains or losses in purchasing power that result from the failure of the monetary items received or paid to move from the average to the year-end price level. This can be readily observed from the journal entries which might be appropriate. Assume a year-end price level of 110 and an average price level of 100 , with sales of $\$ 800,000$, the appropriate entry would be:

$\begin{array}{cr}\text { Accounts Receivable } & \$ 800,000 \\ \text { Loss on monetary item } & 80,000 \\ \text { Sales } & \end{array}$ Sales $\$ \$ 80,000$

or with selling expense of $\$ 100,000$;

$$
\begin{array}{cr}
\text { Selling Expense } & \$ 110,000 \\
\text { Gain on monetary item } & \$ 10,000 \\
\text { Accrued expense } & 100,000
\end{array}
$$

Operating expenses relating to nonmonetary items do not produce such gains or losses in purchasing power. Depreciation, for 
example, is adjusted by the conversion factor applied to the asset itself, namely the ratio of the current year-end price level to the price level at the date of acquisition of the asset.

Acquisitions of nonmonetary items by monetary items, however, will produce gains or losses in purchasing power in the same manner as that shown above for sales and selling expenses.

one final entry is necessary. One must record the gains or losses on monetary items held from the beginning of the year balance of monetary items by a conversion factor of the ratio of the year-end prices to the beginning of the year prices. For example, if there were a balance of $\$ 15,000$ on monetary assets at the beginning of the year with a year-end index of 110 and a beginning of the year index of 100 , the appropriate entry would be:

Loss on monetary items Monetary asset
$\$ 1,500$

$$
\$ 1,500
$$

To illustrate the procedure in detail see Exhibits II and III which follow. Again dollars are used instead of drachmas.

\section{Exhibit II}

Given: X Company was organized in $19 x 0$ when the price level was 50. The building was purchased when the price level was 50. The price level at the end of $19 x 0$ was 100. The average price level during $19 \times 1$ was 133 . The price level at the end of $19 \times 1$ was 200 . Unadjusted balance sheets at December $31,19 \times 0$ and 19x1. Unadjusted income statement for $19 \times 1$.

Required: Prepare an adjusted balance sheet at December $19 \times 1$ and an adjusted income statement for $19 \times 1$.

X Company

Balance sheet

December 31

\begin{tabular}{|c|c|c|c|c|c|}
\hline & $19 \times 0^{*}$ & $19 \times 1$ & & 1980 & $19 \times 1$ \\
\hline Assets & & & iabilities \& Equity & & \\
\hline Cash & $\$ 100$ & $\$ 130$ & Capital stock & $\$ 100$ & $\$ 100$ \\
\hline Building & 500 & 500 & Retained Earnings & 400 & 420 \\
\hline Accum. Dep. & $(100)$ & $(110)$ & & & \\
\hline & $\$ 500$ & $\$ \underline{520}$ & & $\$ 500$ & $\$ 520$ \\
\hline & -- & -- & & -- & --- \\
\hline & & $\begin{array}{c}\mathrm{x} \\
\text { Income }\end{array}$ & $\begin{array}{l}\text { pany } \\
\text { tatement }\end{array}$ & & \\
\hline
\end{tabular}

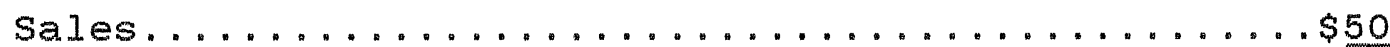

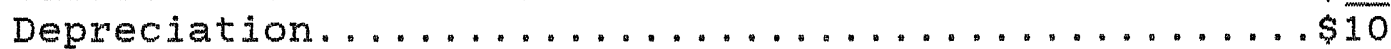

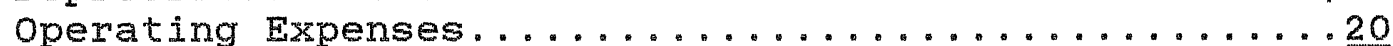

$\$ \overline{30}$

Net Income........................ $\$$. . 20 
* Same as shown in Exhibit I.

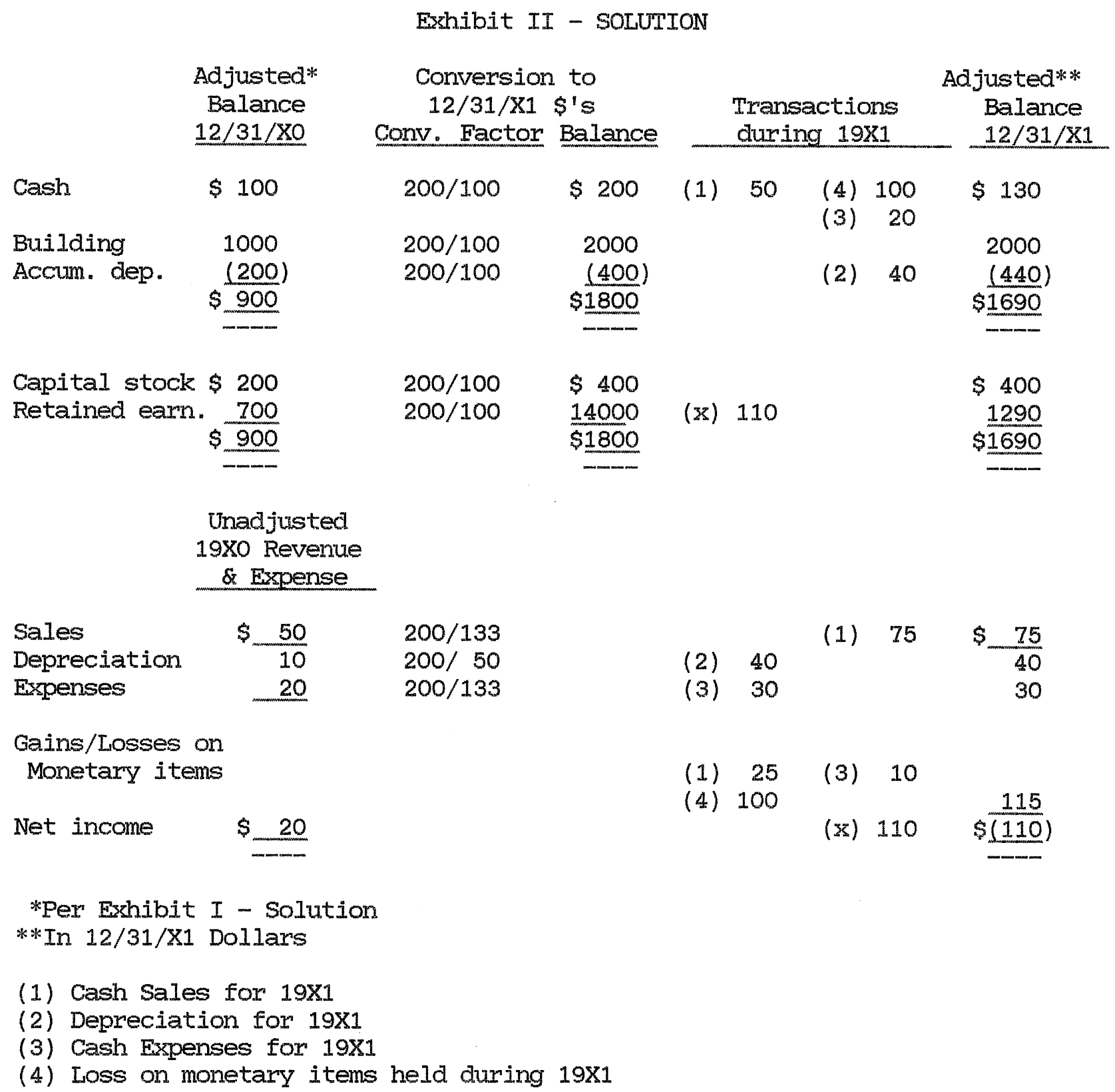




\section{Exhibit III \\ Computation of Gains and Losses on Monetary Items as shown in Exhibit II}

Net Income unadjusted for 19x1

Add back nonmonetary items

Depreciation

Net Revenue from monetary items

Net Revenue adjusted to year end \$'s $200 / 133 \times \$ 30$

Loss on monetary items received during the year

Adjustment of beginning of the year monetary items from beginning of the year dollars to year-end dollars $\$ 100 \times 200 / 100$

Less beginning of year monetary items in beginning of year dollars

Loss on beginning of the year monetary items

Total loss on monetary items
$\$ 20$

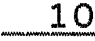

$\$ 30$

$\$ 15$

$\$ 200$

\section{Results}

Null hypothesis $I$ is basically a test to determine if there will be a significant difference between each measure and ratio for each company for the period 1973-83 if the measures and ratios are computed on the basis of adjusted data rather than unadjusted data. To test this hypothesis the student $t$ test was used at a 5\% confidence level. Exhibit IV reveals the results.*

This hypothesis was also tested using the Wilcoxon nonparametric test and the univariate distribution test. These test merely confirmed the results obtained with the student $t$ test. As may be noted there appears to be a significant difference in most pure amounts computed on an adjusted and unadjusted basis. Ratios, on the other hand, have a mixed pattern in terms of results.

The second hypothesis states that for each of the twenty three measures and ratios there will be no significant difference in the trends for the period 1973-83 between those based

\footnotetext{
*All of the statistical test performed were carried out by John Potthast, graduate research assistant, under the direction of Professor A. G. Malliaris, Associate Dean of the Graduate School of Business of Loyola University of Chicago.
} 
upon adjusted data and unadjusted data. The trend was obtained by computing the beta coefficient from the 10 year time series. For each measure and ratio and for each firm two betas were computed using least squares: one beta was obtained from unadjusted measures and ratios and one from adjusted measures and ratios. Because the sample contained 15 firms, the Wilcoxon nonparametric test was used to test whether the differences between betas were statistically significant. The wilcoxon nonparametric test results are given in Exhibit $V$. Note that in fourteen cases out of twenty three, there is a significant difference.

\section{Exhibit IV}

Summary of Acceptance and Rejection of Hypothesis I

\begin{tabular}{|c|c|c|}
\hline & $\begin{array}{l}\text { Number } \\
\text { Reject }\end{array}$ & $\begin{array}{l}\text { mpanies } \\
\text { Accept }\end{array}$ \\
\hline Sales & 15 & 0 \\
\hline Net Income & 3 & 12 \\
\hline Total Assets & 15 & 0 \\
\hline Owners' Equity & 14 & 1 \\
\hline Current Liabilities & 13 & 2 \\
\hline Long term Iiabilities & 11 & 4 \\
\hline Current Assets & 15 & 0 \\
\hline Cost of Goods sold & 15 & 0 \\
\hline Inventory & 15 & 0 \\
\hline Fixed Assets & 14 & 1 \\
\hline Inventory Turnover & 6 & 8 \\
\hline Current Ratio & 12 & 3 \\
\hline Net Income to Sales & 4 & 11 \\
\hline Sales to Total Assets & 11 & 4 \\
\hline Net Income to Total Assets & 3 & 12 \\
\hline Net Income to Owners' Equity & 10 & 5 \\
\hline $\begin{array}{l}\text { Total Liabilities to Total Equity } \\
\text { Long Term Liabilities to Sum of Long }\end{array}$ & 12 & 3 \\
\hline Term Iiabilities and Owners' Equity & 9 & 6 \\
\hline Sales to Fixed Assets & 8 & 7 \\
\hline Net Working Capital & 11 & 4 \\
\hline Sales to Net Working Capital & 2 & 13 \\
\hline Net Working Capital to Total Assets & 5 & 10 \\
\hline Owners' Equity to Total Assets & 11 & 4 \\
\hline
\end{tabular}

Note that "Reject" means that there is a significant difference. 


\title{
Exhibit V \\ Summary of the Acceptance and \\ Rejection of Hypothesis II
}

\begin{abstract}
Reject or Accept

Sales

Net Income

Total Assets

Owners' Equity

Current Liabilities

Long term Liabilities

Current Assets

Cost of Goods sold

Inventory

Fixed Assets

Inventory Turnover

Current Ratio

Net Income to sales

Sales to Total Assets

Net Income to Total Assets

Net Income to Owners' Equity

Total Liabilities to Total Equity

Long Term Liabilities to sum of Long

Term Liabilities and Owners' Equity

Sales to Fixed Assets

Net Working Capital

Sales to Net Working Capital

Net Working Capital to Total Assets

Owners' Equity to Total Assets

R

A

$\mathrm{R}$

$\mathrm{R}$

$\mathrm{R}$

$\mathrm{R}$

$\mathrm{R}$.

$r$

$\mathrm{R}$

R.

A

A

A

$x$

A

R

$r$

A

A

$r$

A

A

$r$

Where: A - Accept the hypothesis

$R$ - Reject at 0.01 confidence level

$r$ - Reject at 0.05 confidence level

Hypothesis III is a test to determine if there are significant differences among companies for each of the years for measures and ratios computed on the adjusted and unadjusted data. Again the student $t$ test was used and the results confirmed by the wilcoxon nonparametric test and the univariate distribution test. As might be expected with the varied nature of assets, liabilities and operation for the various companies, the test showed that there are significant differences each year between companies.
\end{abstract}

\section{Conclusions}

Based upon this study one can conclude that adjusted data generally produces significantly different amounts for amounts frequently used in financial analysis. Ratios based upon adjusted data are not as frequently significantly different as those based upon unadjusted data. Trends seem to follow the 
same pattern. Trends of amounts are frequently different, whereas trends based upon ratios are not as frequently different. Further study into the causes of such results is needed. However, it is believed that the findings with respect to ratios result partially from the mix of monetary and nonmonetary items involved in particular ratios.

With respect to net income, net income before gains and losses on monetary items was used in these tests. Since such gains and losses do not appear on unadjusted statements, it was assumed that a greater degree of comparability would be achieved by omitting them from the computation of net income. As might be expected, net income thus computed was always lower than unadjusted net income because of the adjustments for inflation for cost of goods sold and inventory. For the majority of the companies gains in purchasing power exceeded losses in purchasing power due to the excess of monetary liabilities over monetary assets.

It is interesting to note that purchasing power gains from net monetary liabilities exceeded the adjusted interest costs each year. This suggests that the companies have managed their resources in an appropriate manner to hedge against inflation.

As a general conclusion from the study, one can expect amounts reported on adjusted financial statements to be significantIy different from those reported on unadjusted statements. However, one can not draw the same conclusion with respect to financial ratios; some ratios are likely to be significantly different and others not. 